Volume 10, Issue 6, November-December 2019, pp. 177-190, Article ID: IJM_10_06_018

Available online at http://iaeme.com/Home/issue/IJM?Volume $=10 \&$ Issue $=6$

Journal Impact Factor (2019): 9.6780 (Calculated by GISI) www.jifactor.com

ISSN Print: 0976-6502 and ISSN Online: 0976-6510

\title{
PREDICTIVE ANALYTICS IN HARNESSING FINANCIAL EFFICACY OF BANKS USING CAMEL MODEL
}

\author{
Chinmaya Kumar Rout \\ Research Scholar, Faculty of Management Sciences, \\ Siksha O Anusandhan (Deemed to be University), Bhubaneswar, India \\ Dr. Prafulla Kumar Swain \\ Professor, Faculty of Management Sciences, \\ Siksha O Anusandhan (Deemed to be University), Bhubaneswar, India

\section{Dr. Manoranjan Dash*} \\ Associate Professor, Faculty of Management Sciences, \\ Siksha O Anusandhan (Deemed to be University), Bhubaneswar, India \\ *Corresponding Author Email: manoranjandash@soa.ac.in
}

\begin{abstract}
In India, Cooperative Banking has an idiosyncratic position in the rural credit delivery system. Cooperative Banks are providing timely and easy credit to rural people. The financial efficacy of Cooperative Banks is of immense importance for smooth credit disbursement. In the present study, we have taken 17 District Central Cooperative Banks (DCCBS) of Odisha and attempted to measure their efficacy of finance flow. For this purpose we have used the CAMEL model which is based on five parameters like Capital Adequacy, Asset Quality, Management Quality, Earning Ability and Liquidity. Under each parameter two ratios, are calculated for 10 years and DCCBs are ranked according to their score. Synthesized Index Table is developed by taking the average ranks of each parameter and DCCBs are ranked accordingly.
\end{abstract}

Keywords: Cooperative Banking, Financial Efficacy, District Central Cooperative Banks, CAMEL Model.

Cite this Article: Chinmaya Kumar Rout, Dr. Prafulla Kumar Swain and Dr. Manoranjan Dash, Predictive Analytics in Harnessing Financial Efficacy of Banks Using CAMEL Model, International Journal of Management (IJM), 10 (6), 2019, pp. 177-190.

http://iaeme.com/Home/issue/IJM?Volume=10\&Issue $=6$ 


\section{INTRODUCTION}

Indian economy is an agrarian economy. Most of the people are staying in a rural area and dependent on agriculture. Agricultural credit plays a pivotal role in the development of agriculture. Cooperative banks in India are providing agricultural credit to rural farmers since 1912. The Short Term Cooperative Credit Structure (STCCS) in Odisha comprises of 2709 Primary Agriculture Cooperative Societies (PACS) at the village level, 17 District Central Cooperative Banks (DCCBs) at the middle district level and Odisha State Cooperative Bank ( StCB) at the state level. DCCBs are connecting link between State Cooperative Banks and Primary Agriculture Cooperative Societies.

DCCBs are taking funds from State Cooperative Bank, NABARD and State Government and disburse the funds to agriculture and other allied activities through PACS. As DCCBs are present at a middle level in Short Term Cooperative Credit Structure (STCCS), the efficacy of finance flows should be studied. To analyze the efficacy of finance flow through DCCBs, we have used the CAMEL model. CAMEL model is a supervisory rating system originally developed in the U.S. to classify a bank's overall condition. CAMEL model derives from the five main components of a bank i.e. like Capital Adequacy, Asset Quality, Management Quality, Earning Ability and Liquidity. Under each parameter two ratios, are calculated for 10 years and DCCBs are ranked according to their score. Synthesized Index Table is developed by taking the average ranks of each parameter and DCCBs are ranked accordingly.

\section{REVIEW OF LITERATURE}

As our study is related to the efficacy of finance flow through banks, So we have selected some literature relating to efficiency measurement and performance evaluation of banking sectors.

DeYoung, R. (1998) studied the Management Quality and X-Inefficiency of National Banks with help of CAMEL ratings and the result of their study indicated that the well-managed banks had significantly lower estimated unit costs in comparison poorly managed banks, Shanmugam.R.K and Das. A (2004) studied the efficiency of Indian commercial bank by using stochastic frontier function and found that the state bank group and foreign banks are more efficient than their counterparts, Derviz. A and Podpiera.J (2008) conducted an analysis to identify the determinants of commercial bank ratings in the Czech Republic by using long-term Standard \& Poor 's rating and CAMELS model and the result indicated that S\&P rating demonstrates a predictive accuracy of $70 \%$. and CAMELS model explains $84 \%$ of the variability in the actual data, Ikhide.S.I (2008) studied the operational efficiency of commercial banks in Namibia by using Thick frontier approach (TFA) and the distribution-free approach (DFA) and the result indicated that to reduce operating cost and increase efficiency, the bank should increase its size.Kaur.H.V (2010) make an analysis of banks in India by using the CAMELS model. The study reveals that among public sector banks, the best bank ranking has been shared by Andhra Bank and State Bank of Patiala. Among the private sector banks, Jammu And Kashmir Bank secured the first rank followed by HDFC bank and among the foreign sector banks, Antwerp Bank has been ranked the best followed by JP Morgan Chase Bank, Banker, R. D., Chang, H., \& Lee, S. Y. (2010) examined the Differential impact of Korean banking system reforms on bank productivity by using Data Envelopment Analysis (DEA). The findings of the study state that the capital adequacy ratio is positively associated with banks' technical efficiency and non-performing loans ratio is negatively associated with technical efficiency, Dincer, H., Gencer, G., Orhan, N., \& Sahinbas, K. (2011) evaluate the performance of the Turkish Banking Sector by using CAMELS Ratios and found that Turkey banking sector performance is satisfactory, Gardener, E., Molyneux, P., \& Nguyen-Linh, H. (2011) studied the determinants of the efficiency of banks in South East Asian Countries using Data Envelopment Analysis and Tobit Regression. The results indicate that efficiency 
has significantly declined during the study period. Shahhoseini, M. A., Khassehkhan, S., \& Shanyani, N. (2012) identify the key performance indicators of an Iranian Islamic Bank i.e. K bank on the basis of Balance Scorecard and Analytic Hierarchy Process. Findings of the study indicated that bank policymakers should make the profit through customer's satisfaction, Kumar, M. A., Harsha, G. S., Anand, S., \& Dhruva, N. R. (2012) studied soundness of Indian banks through CAMEL Approach found find that private sector banks showing more soundness than public sector banks and suggested the Government to focus more on public sector banks, Fiordelisi, F., \& Mare, D. S. (2013) examined the probability of default and efficiency of cooperative banks in Italy by using the Discrete-Time Survival Model. The result states that the capital adequacy reduces the probability of default which means higher capital protect the banks against additional loss, Trivedi, K. R. (2013) conducted a study on Surat People's Co-operative bank with CAMEL model and found that the performance of the bank is satisfactory and good except liquidity which is unsatisfactory. So Researcher suggests that the bank should maintain adequate liquidity., Anand, M. B. (2013) studied the performance of banks in India Based on Camel model and found that there's a significant difference between the public sector banks, private sector banks, and foreign banks, Waraich.S, and Dhawan. A (2013) evaluate the performance of Cooperative banks in Punjab by using Camel and found that banks are showing moderate performance on the basis CAMEL parameters, Roman, A., \& Şargu, A. C. (2013) studied the financial Soundness of the Commercial Banks in Romania by using the CAMEL model and banks showing different performance on various parameters of CAMELS model, Makkar, A., \& Singh, S. (2013) analyzed the financial performance of Indian Commercial Banks by using the CAMELS model and the study reveals that there is no significant difference in the financial performance of the public and private sector banks in India but public sector bank should improve their performance to sustain in the competitive market, Vadivel.M.S and Ayyappan.S,(2013) studied the financial efficacy of selected public and private sector banks in India found that due to financial intermediation, by using advanced technology the banks will be able to compete globally. Popovici.M.C (2014) conducted a study to measure the banking efficiency of the European Union on the basis of Return on Average Assets (ROAA) and Return on Average Equity (ROAE). Findings of the study reveal that Bank is affected differently by the international financial crisis and the European Union should take steps towards convergence of ROAA and ROAE to achieve optimum efficiency. Gupta, P. K. (2014) analyzed the financial position and performance of Indian public sector banks using CAMELS model and found that banks got the least rank according to CAMELS model need to improve their performance to maintain the desired level with other banks.Srinivasan, \& Saminathan, Y. P. (2016) made an analysis on Public, Private and Foreign Sector banks in India by using the CAMELS model and the result signifies that the overall performance of within and between Public, Private and foreign Banks are different, so bank secure lower ranks should improve their performance to come into the desired level, Wanke, P., Azad, M. A. K., \& Barros, C. P. (2016) studied efficiency Factors in OECD ( Organisation for Economic Co-operation and Development) banks by using CAMELS model and TOPSIS ( Technique for Order of Preference by Similarity to Ideal Solution) approach. Results reveal that the effects of ownership, trend, and origin of the bank may vary with respect to efficiency levels, whether high or low.Da Silva, T. P., Leite, M., Guse, J. C., \& Gollo, V. (2017) studied on Financial and economic performance of major Brazilian credit cooperatives by using both CAMEL model and Data Envelopment Analysis. They found that there is a positive relationship between the use of variables used in the model and the measurement of the financial performance of credit unions, Alqahtani, F., Mayes, D. G., \& Brown, K. (2017) investigated about the efficiency of Islamic and conventional banks in the Gulf Cooperation Council region by using Data Envelopment Analysis and Stochastic Frontier Analysis before, during and after the global financial crisis (GFC). The result of the study indicates that Islamic banks suffered more in comparison to Conventional banks in terms of 
profit efficiency and cost superiority, Doumpos, M., Hasan, I., \& Pasiouras, F. (2017) studied overall financial strength between Islamic banks and conventional banks by using Bank Overall Financial Strength Index (BSI) which is an improvement over CAMELS model and the study reveals that Islamic banks are the best ones in terms of capital strength, conventional banks are the best ones in terms of expenses management and liquidity, and banks with an Islamic window are the best ones in terms of profitability, Robin.I, Salim.R, and Bloch. H (2018) examined the financial performance of the commercial banks in Bangladesh and found that capital strength and asset quality are the main drivers of profitability. Therefore, an appropriate banking policy aimed at raising capital base and asset quality are important for ensuring a viable banking sector in Bangladesh.From the above literature, we have observed that for measuring the efficiency of bank different models and techniques are used by different researchers all over the world. Odisha states in India which have taken a leading role in cooperative movement No researchers have tried to measure the efficiency of cooperative banks in Odisha. Therefore we have attempted to measure the financial efficacy of District Central Cooperative Banks (DCCBs) banks in Odisha.

\section{OBJECTIVES OF STUDY}

$\square \quad$ To measure the efficacy of finance flows through District Central Cooperative Banks of Odisha.

$\square \quad$ To make a comparative study on the performance of DCCBs in Odisha.

To rank the DCCBs on the basis CAMEL model.

To suggest the various ways of improvement of financial performance banks.

\section{RESEARCH METHODOLOGY}

For our study, we have taken 17 District Central Cooperative Banks (DCCBs) operating in Odisha. Mainly our study based on secondary data. Data in our research are derived from the annual report of OSCB (Odisha State Cooperative Bank) and NAFSCOB (National Federation of State Cooperative Bank). For the study, 10 years (2007-08 to 2016-17) data are taken into consideration. For analyzing the efficacy of finance flow through DCCBs CAMEL model has been used. CAMEL stands for Capital Adequacy, Asset Quality, Management Efficiency, Earning Ability and Liquidity position. The items used in our research and the formula for their calculation is presented in Table.1. Under each parameter of CAMEL two ratios are calculated for 10 years and an average is taken. Basing upon average score DCCBs are ranked. At the end of the analysis, a Synthesized Index Table is developed by taking average ranks of each parameter and DCCBs are ranked accordingly.

\subsection{CAMEL Model}

Table 1 CAMEL parameters and their calculation method

\begin{tabular}{|l|l|l|}
\hline \multicolumn{1}{|c|}{ CAMEL variables } & \multicolumn{1}{|c|}{ Ratios } & \multicolumn{1}{|c|}{ Calculation method } \\
\hline Capital Adequacy & $\begin{array}{l}\text { 1) Capital Adequacy ratio } \\
\text { 2) Debt-Equity ratio }\end{array}$ & $\begin{array}{l}\text { (Capital tier I +tier II)/RWA } \\
\text { (Borrowings+ Deposits)/Net Worth }\end{array}$ \\
\hline Asset Quality & $\begin{array}{l}\text { 1) Net Non-Performing Asset (NPA) by } \\
\text { total assets } \\
\text { 2) Net NPA by net advances. }\end{array}$ & $\begin{array}{l}\text { Net NPA/ Total Assets } \\
\text { Net NPA/Net Advances }\end{array}$ \\
\hline Management Quality & $\begin{array}{l}\text { 1) Cost of Management per Employee } \\
\text { 2) Business Per Employee }\end{array}$ & $\begin{array}{l}\text { Cost of Management/ No .of } \\
\text { Employees } \\
\text { Total Business/ No .of } \\
\text { Employees }\end{array}$ \\
\hline
\end{tabular}




\begin{tabular}{|l|l|l|}
\hline Earnings Ability & 1)Return on Assets (ROA) & Net Income/Total Assets \\
& 2)Return on Equity (ROE) & Net Income / Shareholders' equity \\
\hline Liquidity Position & 1)Liquid Assets/Total Deposits & Liquid Assets / Total Deposits \\
& 2)Liquid Assets/Total Assets & Liquid Assets / Total Assets \\
\hline
\end{tabular}

Authors design

Note: RWA-Risk Weighted Assets

NPA-Non Performing Assets

Capital Adequacy (C) parameter is a vital measure for the overall financial health of a bank because it promises to soak up the losses arises due to by the manifestation of certain risks or certain indispensable macroeconomic imbalances. For the measurement of the capital adequacy, we have used two ratios i.e. Total capital to total assets ratio and Debt to Equity ratio

Asset Quality (A) is a crucial parameter that measures the strength of a bank. In banks, the quality of the assets is determined by the quality of the loan and advances because this category of assets represents a major share in the overall balance sheet of a bank. To know the asset quality, we have used two ratios i.e. Net Non-Performing Asset (NPA) by Total Assets and Net NPA by Net Advance.

Management Quality (M) is of great importance for the health and stability of a bank. Management is the most pioneering indicator of condition and a major determinant of whether a bank is having the ability to correctly diagnose and respond to financial stress or not. To analyze the capability of management, we have calculated two ratios i.e. Cost of Management per Employee and Business Per Employee

Earning Ability (E) of banks is analyzed by calculating two ratios i.e. Return on assets and Return on equity. Return on Assets denotes how bank assets are capable of earning revenue whereas Return on Equity reflects the profit-generating capacity of the bank's own capital.

Liquidity Position (L) is the crucial ingredient for a bank. It acts as important elements that evaluate the operational efficiency of a bank because it indicates the capacity of a bank to pay its short term loans and face unexpected withdrawal of depositors. We have allotted higher rank for banks with higher liquidity ratio. Liquidity has been compared based on the two parameters, i.e. Liquid Assets/Total Deposits and Liquid Assets/Total Assets.

\section{RESULT \& DISCUSSION}

In this section of our research, we have analyzed the efficacy of finance flow of 17 DCCBs in Odisha based on CAMEL model

\subsection{Capital Adequacy}

To analyze the Capital Adequacy, we have selected two parameters. The first parameter is Capital Adequacy ratio and the second parameter is the Debt-Equity ratio. The Capital Adequacy ratio is popularly known as CRAR which signifies Capital to Risk Weighted Assets Ratio and Debt-Equity Ratio signifies Total Borrowings plus deposits to Equity capital. We have assigned the first rank to that DCCB who is having the highest score on basis of Capital Adequacy and vice versa. This indicator determines the bank's capacity to meet the time liabilities and other risks such as credit risk, operational risk, etc. On the basis of Debt-Equity ratio, those DCCB is having the lowest score assigned the highest rank and vice versa. Banks carry greater debt amounts because the money they borrow is also the money they lend. To put it another way, the major product that banks sell is debt. Therefore, it is logical that they have more of that product on hand that is common in other industries. The Capital Adequacy detail is given in Table-2. 
On the basis of first parameter Capital Adequacy ratio Bolangir DCCB secured 21.95\% and obtained the first rank, Puri-Nimapara DCCB secured 20.80\% and obtained the second rank, Aska DCCB secured $19.12 \%$ and obtained the third rank, Nayagarh DCCB secured $18.19 \%$ and obtained the fourth rank. Sundergarh DCCB secured 8.62\% and obtained the last rank among the DCCBs. During our study period, all the DCCBs of Odisha are satisfying the Capital Adequacy norm i.e. 9\% CRAR which is being fixed by Reserve Bank of India for all banks operating in India except Sundergarh DCCB. So on the basis of the first parameter, the position of all the DCCBs in Odisha are quite good.

Coming to the second parameter i.e. Debt-Equity ratio, the Puri-Nimapara DCCB is having a score of $6.69 \%$ and obtained the first rank, Nayagarh DCCB secured $7.95 \%$ and obtained the second rank and so on. Sundergarh DCCB secured $17.43 \%$ and secured the last rank among all the DCCBs. All the DCCBs of Odisha are having excessive borrowings than standard banking norms. Central Government through NABARD and State Government through State Cooperative Bank injecting more credit to agriculture and allied sectors with the help of DCCBs. Members contribution as equity capital is less in comparison to borrowings in DCCBs of Odisha.

Looking at the average rank, Puri-Nimapara DCCB secured first average score, Aska DCCB and Nayagarh DCCB both secured second and third average score and so on. All the DCCBs of Odisha are satisfying the Capital Adequacy Requirement.

Table 2 Capital Adequacy

\begin{tabular}{|c|c|c|c|c|c|}
\hline \multirow[t]{2}{*}{ Name of the DCCBs } & \multicolumn{2}{|c|}{ Capital Adequacy Ratio } & \multicolumn{2}{|c|}{ Debt-Equity ratio } & \multirow[b]{2}{*}{ Average Rank } \\
\hline & Average \% & Rank & Average \% & Rank & \\
\hline Angul DCCB & 13.65 & 9 & 13.42 & 13 & 11 \\
\hline Aska DCCB & 19.12 & 3 & 9.04 & 3 & 3 \\
\hline Balasore DCCB & 11.47 & 13 & 12.84 & 11 & 12 \\
\hline Banki DCCB & 11.44 & 14 & 9.45 & 4 & 9 \\
\hline Berhampur DCCB & 18.08 & 5 & 13.02 & 12 & 8.5 \\
\hline Bhawanipatna DCCB & 15.55 & 6 & 10.97 & 5 & 5.5 \\
\hline Bolangir DCCB & 21.95 & 1 & 11.82 & 8 & 4.5 \\
\hline Boudh DCCB & 13.73 & 8 & 11.27 & 6 & 7 \\
\hline Cuttack DCCB & 15.43 & 7 & 12.39 & 9 & 8 \\
\hline Keonjhar DCCB & 10.46 & 16 & 16.07 & 16 & 16 \\
\hline Khurda DCCB & 11.23 & 15 & 11.44 & 7 & 11 \\
\hline Koraput DCCB & 12.76 & 11 & 13.75 & 15 & 13 \\
\hline Mayurbhanj DCCB & 12.36 & 12 & 13.58 & 14 & 13 \\
\hline Nayagarh DCCB & 18.19 & 4 & 7.95 & 2 & 3 \\
\hline Puri-Nimapara DCCB & 20.80 & 2 & 6.69 & 1 & 1.5 \\
\hline Sambalpur DCCB & 12.81 & 10 & 12.69 & 10 & 10 \\
\hline Sundergarh DCCB & 8.62 & 17 & 17.43 & 17 & 17 \\
\hline
\end{tabular}

Source: Authors calculations based annual report of StCB and NAFSCOB

\subsection{Asset Quality}

To know about the Asset Quality of the DCCBs in Odisha, we have used two parameters i.e. Net NPA to Total Assets and Net NPA to Net Advance. The detail of the calculation is given in Table-3. The major proportion of the bank's asset is loans and Advances. Non-Performing Assets (NPA) is unrecovered part of loan and advances to the customers during the period. In our analysis for Asset Quality, the first parameter is Net NPA to Total Assets. Basing upon this parameter Sundergarh DCCB is having 5.01\% and secured the first position, Koraput DCCB is having a score of $5.25 \%$ and obtained the second position, Keonjhar DCCB is having $5.29 \%$ score and obtained the third position etc.Bolangir DCCB is having a score of $21.11 \%$ and secured the last position on basis of Net NPA to Total Assets parameter. Among the 17 DCCBs of Odisha 9 DCCBs have less than 10\% score and 8 DCCBs have more than $10 \%$ score basing 
upon the ratio of Non-Performing Assets as a percentage of Total Assets during the study period.

On the basis of the second parameter under Asset Quality perusal .i.e. Net NPA to Net Advance Puri-Nimapara DCCB secured $6.54 \%$ and obtained the first rank, Balasore DCCB secured $9.08 \%$ and obtained the second rank, Sundergarh DCCB secured $9.39 \%$ and get third rank, etc. Bolangir DCCB secured 33.81\% and get the last rank among all the DCCBs of Odisha. Here one thing we have observed that basing upon both the parameters of Asset Quality investigation Bolangir DCCB secured lowest rank means more Non-Performing Assets as a percentage of Total Assets as well as Net Advance because Bolangir district in Odisha is a tribal populated district. Most of the people belong to Schedule Tribe (ST) categories. Due to their backwardness and lack of education, they are unable to repay the loan. So in Bolangir DCCB Non-Performing Asset percentage is more in comparison to other DCCBs.

Table 3 Asset Quality

\begin{tabular}{|c|c|c|c|c|c|}
\hline \multirow{2}{*}{$\begin{array}{l}\text { Name of the } \\
\text { DCCBs }\end{array}$} & \multicolumn{2}{|c|}{ NetNPA/ Total Assets } & \multicolumn{2}{|c|}{ Net NPA/ Net Advances } & \multirow[b]{2}{*}{ Average Rank } \\
\hline & Average $\%$ & Rank & Average \% & Rank & \\
\hline Angul DCCB & 6.02 & 5 & 10.87 & 8 & 6.5 \\
\hline Aska DCCB & 12.56 & 15 & 12.21 & 12 & 13.5 \\
\hline Balasore DCCB & 6.08 & 6 & 9.08 & 2 & 4 \\
\hline Banki DCCB & 16.98 & 16 & 23.18 & 16 & 16 \\
\hline Berhampur DCCB & 6.68 & 9 & 15.72 & 15 & 12 \\
\hline $\begin{array}{l}\text { Bhawanipatna } \\
\text { DCCB }\end{array}$ & 6.21 & 7 & 9.72 & 4 & 5.5 \\
\hline Bolangir DCCB & 21.11 & 17 & 33.81 & 17 & 17 \\
\hline Boudh DCCB & 9.46 & 14 & 12.71 & 13 & 13.5 \\
\hline Cuttack DCCB & 6.50 & 8 & 11.04 & 9 & 8.5 \\
\hline Keonjhar DCCB & 5.29 & 3 & 10.44 & 7 & 5 \\
\hline Khurda DCCB & 9.10 & 13 & 12.06 & 11 & 12 \\
\hline Koraput DCCB & 5.25 & 2 & 9.97 & 6 & 4 \\
\hline Mayurbhanj DCCB & 8.41 & 12 & 14.39 & 14 & 13 \\
\hline Nayagarh DCCB & 7.03 & 10 & 9.90 & 5 & 7.5 \\
\hline $\begin{array}{l}\text { Puri-Nimapara } \\
\text { DCCB }\end{array}$ & 5.51 & 4 & 6.54 & 1 & 2.5 \\
\hline Sambalpur DCCB & 7.71 & 11 & 11.76 & 10 & 10.5 \\
\hline Sundergarh DCCB & 5.01 & 1 & 9.39 & 3 & 2 \\
\hline
\end{tabular}

Source: Authors calculations based annual report of StCB and NAFSCOB

Looking at the average rank on Asset Quality parameter Sundergarh DCCB secured the first position, Puri-Nimapara DCCB secured the second position, Balasore DCCB and Koraput DCCB secured the third position jointly and so on. On the basis of Asset Quality parameter, DCCBs in Odisha is having moderate performance level.

\subsection{Management Quality}

To know the management quality of DCCBs, we have used two parameters i.e. Cost of management per Employee and Business Per Employee. Details about Management quality are given in Table.4.

Here the analysis about the expenditure incurred for an employee by a bank and Income earned by an employee in that bank, which otherwise is the outflow and inflow analysis of finance during a particular period. In the first parameter, Cost of Management per Employee that DCCB secured the lowest score assigned the highest rank and those DCCB secured the highest score assigned lowest rank because it costs part. Other Parameter i.e. Business per Employee that DCCB secured the highest score assigned the highest rank and those DCCB secured the lowest score assigned lowest rank.

Basing upon the Cost of Management per Employee, Boudh DCCB incurred the lowest cost which is $2.68 \%$ and secured the first rank whereas Balasore DCCB incurred the highest cost of 
management per employee i.e 7.35\% and secured the lowest rank among the 17 DCCBs of Odisha. Other DCCBs like Koraput DCCB scored 3.09\%, Puri-Nimapara DCCB scored 3.18 $\%$, Mayurbhanj DCCB scored 4.06\%, Sundergarh DCCB scored $4.12 \%$, secured second, third, fourth and fifth rank respectively.

Table 4 Management Quality

\begin{tabular}{|c|c|c|c|c|c|}
\hline \multirow[t]{2}{*}{ Name of the DCCBs } & \multicolumn{2}{|c|}{$\begin{array}{c}\text { Cost of Management per } \\
\text { Employee }\end{array}$} & \multicolumn{2}{|c|}{ Business Per Employee } & \multirow[t]{2}{*}{ Average Rank } \\
\hline & Average \% & Rank & Average \% & Rank & \\
\hline Angul DCCB & 5.07 & 11 & 6.69 & 3 & 7 \\
\hline Aska DCCB & 4.90 & 10 & 7.14 & 2 & 6 \\
\hline Balasore DCCB & 7.35 & 17 & 7.40 & 1 & 9 \\
\hline Banki DCCB & 4.15 & 6 & 3.21 & 14 & 10 \\
\hline Berhampur DCCB & 5.63 & 12 & 4.21 & 9 & 10.5 \\
\hline Bhawanipatna DCCB & 6.49 & 15 & 1.93 & 16 & 15.5 \\
\hline Bolangir DCCB & 5.98 & 14 & 5.17 & 6 & 10 \\
\hline Boudh DCCB & 2.68 & 1 & 4.71 & 8 & 4.5 \\
\hline Cuttack DCCB & 5.82 & 13 & 5.04 & 7 & 10 \\
\hline Keonjhar DCCB & 4.46 & 7 & 3.80 & 12 & 9.5 \\
\hline Khurda DCCB & 6.54 & 16 & 4.06 & 10 & 13 \\
\hline Koraput DCCB & 3.09 & 2 & 3.84 & 11 & 6.5 \\
\hline Mayurbhanj DCCB & 4.06 & 4 & 3.19 & 15 & 9.5 \\
\hline Nayagarh DCCB & 4.57 & 8 & 3.34 & 13 & 10.5 \\
\hline $\begin{array}{l}\text { Puri-Nimapara } \\
\text { DCCB }\end{array}$ & 3.18 & 3 & 1.91 & 17 & 10 \\
\hline Sambalpur DCCB & 4.61 & 9 & 5.39 & 5 & 7 \\
\hline Sundergarh DCCB & 4.12 & 5 & 5.69 & 4 & 4.5 \\
\hline
\end{tabular}

Basing upon the Business per Employee parameter Balasore DCCB shown the highest score i.e $7.40 \%$ and secured the first rank whereas Puri-Nimapara DCCB recorded $1.91 \%$ score and secured the lowest rank among the DCCBs of Odisha. Aska DCCB 7.14\% score, Angul DCCB $6.69 \%$ score, Sundergarh DCCB 5.69\% score and secured second, third, fourth, fifth rank respectively.

On the basis of the average rank of Management Quality parameter, none of the DCCB noticed less cost and more revenue per employee. Balasore DCCB showed the highest cost and highest revenue per employee. Here management of DCCBs in Odisha fails to catch the efficiency line i.e. Less Cost More Earning. Looking to average rank column Sundergarh DCCB and Cuttack DCCB both secured 4.5 and starts with the first rank and Aska DCCB secured 6 average ranks and so on.

\subsection{Earning Ability}

To analyze the Earning Ability of the DCCBs we have used two parameters i.e. Return on Assets and Return on Equity which can be calculated through the ratio of Net Income to Total Asset and Net Income to Shareholder's Equity respectively. The Earning ability is given in Table-3.

On the basis of first parameter i.e. return on Assets, Sambalpur DCCB secured the first position, Bolangir DCCB secured the second position, Bhawanipatna DCCB secured the third position and Banki DCCB secured the last position. No DCCBs of Odisha are able to generate a $1 \%$ return on the total asset during the study period.

Coming to the second parameter i.e. Return on Equity, Sambalpur DCCB secured the first position which is $11.69 \%$ and Koraput DCCB secured the last position which is $0.68 \%$. Bhawanipatna DCCB is having 9.52\% score, the secured second position and Puri-Nimapara DCCB secured the third position by having a score of $6.86 \%$. 
Table 5 Earnings Ability

\begin{tabular}{|l|c|c|c|c|c|}
\hline \multirow{2}{*}{ Name of the DCCBs } & \multicolumn{2}{|c|}{ Return on Assets } & \multicolumn{2}{c|}{ Return on Equity } & \multirow{2}{*}{ Average Rank } \\
\cline { 2 - 5 } & Average \% & Rank & Average \% & Rank & (4.5 \\
\hline Angul DCCB & 0.08854 & 15 & 1.4940 & 14 & 8.5 \\
\hline Aska DCCB & 0.26303 & 8 & 3.1758 & 9 & 5.5 \\
\hline Balasore DCCB & 0.51816 & 5 & 4.4444 & 6 & 14 \\
\hline Banki DCCB & 0.06731 & 17 & 1.9395 & 11 & 8 \\
\hline Berhampur DCCB & 0.32109 & 6 & 3.0799 & 10 & 2.5 \\
\hline Bhawanipatna DCCB & 0.70854 & 3 & 9.5281 & 2 & 3.5 \\
\hline Bolangir DCCB & 0.84198 & 2 & 5.1633 & 5 & 11.5 \\
\hline Boudh DCCB & 0.10548 & 11 & 1.8759 & 12 & 5.5 \\
\hline Cuttack DCCB & 0.29741 & 7 & 5.2142 & 4 & 9 \\
\hline Keonjhar DCCB & 0.16493 & 10 & 3.5531 & 8 & 13.5 \\
\hline Khurda DCCB & 0.08875 & 14 & 1.5533 & 13 & 14.5 \\
\hline Koraput DCCB & 0.10179 & 12 & 0.6820 & 17 & 14 \\
\hline Mayurbhanj DCCB & 0.09172 & 13 & 1.1520 & 15 & 16 \\
\hline Nayagarh DCCB & 0.06788 & 16 & 0.8473 & 16 & 3.5 \\
\hline Puri-Nimapara DCCB & 0.63080 & 4 & 6.8669 & 3 & 1 \\
\hline Sambalpur DCCB & 0.99030 & 1 & 11.699 & 1 & 8 \\
\hline Sundergarh DCCB & 0.22355 & 9 & 3.9544 & 7 & \\
\hline
\end{tabular}

Source: Authors calculations based annual report of StCB and NAFSCOB

On the basis of average rank of Earning Ability parameter Sambalpur DCCB obtained the first rank Bhawanipatna DCCB second rank, Puri-Nimapara DCCB and Bolangir DCCB both have secured third and fourth rank mutually, Cuttack DCCB and Balasore DCCB both have obtained fifth and sixth position and so on (Table.5). The DCCBs of Odisha have not noticed good performance on the basis of Return on Asset but on the basis of Return on Equity, a few DCCBs are secured satisfied rank. So overall Earning Ability all the DCCBs of Odisha are not satisfactory.

\subsection{Liquidity Position}

The focal aim behind the liquidity parameter is to analyze the capacity of a bank to meet the unexpected demand of deposit holders at a particular time. The liquidity position of the banks from our sample is determined by two ratios namely Liquid Assets to Total Deposits and Liquid Assets to Total Assets. Aggregate liquidity position has been presented in Table.6

Table 6 Liquidity Position

\begin{tabular}{|c|c|c|c|c|c|}
\hline \multirow{2}{*}{ Name of the DCCBs } & \multicolumn{2}{|c|}{$\begin{array}{c}\text { Liquid Assets/Total } \\
\text { Deposit }\end{array}$} & \multicolumn{2}{c|}{$\begin{array}{c}\text { Liquid Asset/Total } \\
\text { Asset }\end{array}$} & \multirow{2}{*}{ Average Rank } \\
\cline { 2 - 5 } & $\begin{array}{c}\text { Average } \\
\text { \% }\end{array}$ & Rank & Average \% & \multirow{2}{*}{} \\
\hline Angul DCCB & 6.71 & 14 & 3.50 & 13 & 13.5 \\
\hline Aska DCCB & 10.93 & 6 & 3.97 & 11 & 8.5 \\
\hline Balasore DCCB & 0.91 & 17 & 0.67 & 17 & 17 \\
\hline Banki DCCB & 7.12 & 13 & 2.22 & 16 & 11 \\
\hline Berhampur DCCB & 6.54 & 15 & 4.67 & 7 & 2 \\
\hline Bhawanipatna DCCB & 15.16 & 3 & 8.76 & 1 & 6.5 \\
\hline Bolangir DCCB & 8.92 & 10 & 7.18 & 3 & 10.5 \\
\hline Boudh DCCB & 9.53 & 9 & 3.94 & 12 & 6 \\
\hline Cuttack DCCB & 11.67 & 4 & 4.64 & 8 & 15 \\
\hline Keonjhar DCCB & 6.09 & 16 & 3.20 & 14 & \\
\hline Khurda DCCB & 10.69 & 7 & 4.32 & 9 & \\
\hline Koraput DCCB & 7.56 & 12 & 2.83 & 15 & 13.5 \\
\hline
\end{tabular}




\begin{tabular}{|c|c|c|c|c|c|}
\hline Mayurbhanj DCCB & 9.66 & 8 & 5.13 & 4 & 6 \\
\hline Nayagarh DCCB & 20.40 & 1 & 7.23 & 2 & 1.5 \\
\hline Puri-Nimapara DCCB & 18.77 & 2 & 4.74 & 5 & 3.5 \\
\hline Sambalpur DCCB & 11.16 & 5 & 4.68 & 6 & 5.5 \\
\hline Sundergarh DCCB & 7.96 & 11 & 4.11 & 10 & 10.5 \\
\hline
\end{tabular}

Source: Authors calculations based annual report of StCB and NAFSCOB

Nayagarh DCCB secured the highest position on the basis of Liquid Assets to Total deposit ratio whereas Bhawanipatna DCCB secured the highest position in terms of Liquid Assets to Total Asset Ratio. But on the basis of average rank Nayagarh DCCB came first, Bhawanipatna DCCB is having the second rank, Puri-Nimapara DCCB secured the third rank and so on, based upon the average score of two ratios. Balasore DCCB secured lowest rank i.e $17^{\text {th }}$ among all other DCCBs. On the basis of first parameter Liquid Assets to Total deposit, the position of liquidity ranges from $0.91 \%$ to $20.40 \%$ which are of Balasore DCCB and Nayagarh DCCB respectively. Except for Balasore DCCB, all other 16 DCCBs have recorded more than $6 \%$. It signifies all the DCCBs in Odisha are capable enough to meet the immediate withdrawal demand of depositors. In terms of another parameter i.e Liquid Assets to Total Asset Bhawanipatna DCCB is having $8.76 \%$ as the highest range and Balasore DCCB is having $0.67 \%$ as the lowest range. Except for Balasore DCCB, all other DCCBs in Odisha are having a score of more than $2 \%$. So overall liquidity position of all the DCCBs in Odisha are satisfactory.

\subsection{Synthesized Index}

The synthesized index is developed by taking the average of each parameter of the CAMEL model. Basing upon the synthesized index the overall ranking of DCCBs in are made in Table.7

Table 7 Synthesized Index Table

\begin{tabular}{|c|c|c|c|c|c|c|c|}
\hline $\begin{array}{c}\text { Name Of } \\
\text { DCCB }\end{array}$ & $\begin{array}{c}\text { Capital } \\
\text { Adequacy }\end{array}$ & $\begin{array}{c}\text { Asset } \\
\text { Quality }\end{array}$ & $\begin{array}{c}\text { Management } \\
\text { Efficiency }\end{array}$ & $\begin{array}{c}\text { Earning } \\
\text { Ability }\end{array}$ & $\begin{array}{c}\text { Liquidity } \\
\text { Position }\end{array}$ & $\begin{array}{c}\text { Synthesized } \\
\text { Index }\end{array}$ & Rank \\
\hline Angul DCCB & 11 & 6.5 & 7 & 14.5 & 13.5 & 10.5 & 13 \\
\hline Aska DCCB & 3 & 13.5 & 6 & 8.5 & 8.5 & 7.9 & 6 \\
\hline Balasore DCCB & 12 & 4 & 9 & 5.5 & 17 & 9.5 & 10 \\
\hline Banki DCCB & 9 & 16 & 10 & 14 & 14.5 & 12.7 & 17 \\
\hline $\begin{array}{c}\text { Berhampur } \\
\text { DCCB }\end{array}$ & 8.5 & 12 & 10.5 & 8 & 11 & 10 & 11 \\
\hline $\begin{array}{c}\text { Bhawanipatna } \\
\text { DCCB }\end{array}$ & 5.5 & 5.5 & 15.5 & 2.5 & 2 & 6.2 & 2 \\
\hline Bolangir DCCB & 4.5 & 17 & 10 & 3.5 & 6.5 & 8.3 & 7 \\
\hline $\begin{array}{c}\text { Boudh DCCB } \\
\text { Cuttack DCCB }\end{array}$ & 7 & 13.5 & 4.5 & 11.5 & 10.5 & 9.4 & 9 \\
\hline Keonjhar DCCB & 16 & 5 & 10 & 5.5 & 6 & 7.6 & 4 \\
\hline Khurda DCCB & 11 & 12 & 13 & 9 & 15 & 10.9 & 14 \\
\hline Koraput DCCB & 13 & 4 & 6.5 & 14.5 & 13.5 & 10.3 & 12 \\
\hline $\begin{array}{c}\text { Mayurbhanj } \\
\text { DCCB }\end{array}$ & 13 & 13 & 9.5 & 14 & 6 & 11.1 & 15 \\
\hline $\begin{array}{c}\text { Nayagarh } \\
\text { DCCB }\end{array}$ & 3 & 7.5 & 10.5 & 16 & 1.5 & 7.7 & 5 \\
\hline $\begin{array}{c}\text { Puri-Nimapara } \\
\text { DCCB }\end{array}$ & 1.5 & 2.5 & 10 & 3.5 & 3.5 & 4.2 & 1 \\
\hline $\begin{array}{c}\text { Sambalpur } \\
\text { DCCB }\end{array}$ & 10 & 10.5 & 7 & 1 & 5.5 & 6.8 & 3 \\
\hline $\begin{array}{c}\text { Sundergarh } \\
\text { DCCB }\end{array}$ & 17 & 2 & 4.5 & 8 & 10.5 & 8.4 & 8 \\
\hline
\end{tabular}


Source: Authors calculations based annual report of StCB and NAFSCOB

From the above Table.7, it clearly indicates that Puri-Nimapara DCCB secured the first position on the average ranking. Bhawanpatna DCCB, Sambalpur DCCB, Cuttack DCCB, Nayagarh DCCB, Aska DCCB have secured second, third, fourth, fifth and sixth position respectively. Banki DCCB secured the last position based on average rank. Table. 8 reflects the name of DCCBs and their average ranking based on rank 1 to rank 17.

\subsection{Ranking on CAMEL Model}

Table 8

\begin{tabular}{|c|c|}
\hline Name of DCCB & Average rank \\
\hline Puri -Nimapara DCCB & 1 \\
\hline Bhawanipatna DCCB & 2 \\
\hline Sambalpur DCCB & 3 \\
\hline Cuttack DCCB & 4 \\
\hline Nayagarh DCCB & 5 \\
\hline Aska DCCB & 6 \\
\hline Bolangir DCCB & 7 \\
\hline Sundergarh DCCB & 8 \\
\hline Boudh DCCB & 9 \\
\hline Balasore DCCB & 10 \\
\hline Berhampur DCCB & 11 \\
\hline Koraput DCCB & 12 \\
\hline Angul DCCB & 13 \\
\hline Keonjhar DCCB & 14 \\
\hline Mayurbhanj DCCB & 15 \\
\hline Khurda DCCB & 16 \\
\hline Banki DCCB & 17 \\
\hline
\end{tabular}

Source: Authors ranking based on Synthesized Index Table

\section{FINDINGS \& SUGGESTIONS}

17 District Central Cooperative Banks (DCCBs) in Odisha are showing better performance on the basis of Liquidity and Capital Adequacy and have recorded a poor performance on the basis of Earning Ability, Management Quality and on the basis of Asset Quality all the DCCBs are showing moderate performance. Ranking on the basis of the average score of five parameters is shown in Table.8.

The major problems that DCCBs are facing in Odisha are lack of advance technological to cope up with the growing need of customers, poor infrastructural facilities, excessive political interference, stiff competition from commercial banks, lack of awareness among the customers regarding repayment of loans which leads to NPA, lack of professional expertise for management, high Credit Deposit ratio in comparison to commercial banks, frequent natural calamities at the time of harvesting season, lack of awareness for crop insurance and many more. In spite of the above problems, cooperative banks are providing timely and easy credit to rural people. Government through cooperative banks injecting the funds to rural farmers those are continuously engaged in agriculture and other allied activities.

From the above study, we are suggesting the following measures to be taken

Supervisory measures which are applicable to commercial banks, should not be applicable to cooperative banks, hence RBI should develop separate norms for cooperative banks because they are mainly working in rural area. 
These banks should be given sufficient time period to cope up with RBI conditions.

$\square \quad$ State government should contribute more capital to cooperative banks because these banks are under its control.

$\square \quad$ Public sector undertakings should be allowed to subscribe to the share capital of these cooperative banks.

Awareness should be created for repayment of loans and crop insurance should be essential for each farmer which will make strong the recovery status.

Staffs should be work freely with less political interference.

\section{CONCLUSION}

In India, cooperative banks are serving the real credit need from the last 106 years. Without cooperative banks rural and agricultural development is impossible. In Odisha, the role of the cooperative structure is of prime importance. Again the importance of DCCBs is more. In this paper, we have tried to measure the efficacy of finance flow through DCCBs in Odisha by using the CAMEL model. On the basis of Liquidity and Capital, Adequacy DCCBs are showing better performance whereas on the basis of Earning Ability, Management Quality DCCBs are showing poor performance and on the basis of Asset Quality, all the DCCBs are showing moderate performance.

Here efficacy of finance flow is not $100 \%$ satisfactory, it is moderate. To achieve the desired result suggestions should be implemented, Reserve Bank of India and Government should put forward to strengthen cooperative banks.

\section{REFERENCES}

[1] Alqahtani, F., Mayes, D. G., \& Brown, K, Islamic bank efficiency compared to conventional banks during the global crisis in the GCC region. Journal of International Financial Markets, Institutions, and Money, 51, 2017, 58-74.

[2] Anand, M. B, Bank performance in India: a study based on camel framework. International Journal of Banking, Risk and Insurance, 1(1), 2013, 24.

[3] Banker, R. D., Chang, H., \& Lee, S. Y, Differential impact of Korean banking system reforms on bank productivity. Journal of Banking \& Finance, 34(7), 2010, pp 1450-1460.

[4] Da Silva, T. P., Leite, M., Guse, J. C., \& Gollo, V, Financial and economic performance of major Brazilian credit cooperatives. Contaduríay Administración, 62(5), 2017, pp 14421459 .

[5] DeYoung, R, Management quality and X-inefficiency in national banks. Journal of Financial Services Research, 13(1), 1998, pp 5-22.

[6] Derviz, A., \& Podpiera, J, Predicting bank CAMELS and S\&P ratings: the case of the Czech Republic. Emerging Markets Finance and Trade, 44(1), 2008, pp 117-130.

[7] Dincer, H., Gencer, G., Orhan, N., \& Sahinbas, K, A performance evaluation of the Turkish banking sector after the global crisis via CAMELS ratios. Procedia-Social and Behavioral Sciences, 24, 2011, pp 1530-1545.

[8] Doumpos, M., Hasan, I., \& Pasiouras, F, Bank overall financial strength: Islamic versus conventional banks. Economic Modelling, 64, 2017, pp 513-523. 
[9] Fiordelisi, F., \& Mare, D. S, The probability of default and efficiency in cooperative banking. Journal of International Financial Markets, Institutions and Money, 26, 2013, pp $30-45$.

[10] Gardener, E., Molyneux, P., \& Nguyen-Linh, H, Determinants of efficiency in South East Asian banking. The Service Industries Journal, 31(16), 2011, 2693-2719.

[11] Gupta, P. K, An analysis of Indian public sector banks using CAMEL approach. IOSR Journal of Business and Management, 16(1), 2014, pp 94-102.

[12] Ikhide, S. I, measuring the operational efficiency of commercial banks in Namibia. South African Journal of Economics, 76(4), 2008, pp 586-595.

[13] Kaur, H. V, Analysis of banks in India-A CAMEL approach. Global Business Review, 11(2), 2010, pp 257-280.

[14] Makkar, A., \& Singh, S, Analysis of the financial performance of Indian commercial banks: A comparative study. Indian Journal of Finance, 7(5), 2013, pp 41-49.

[15] Mishra, A., \& Burns, K, The effect of liquidity shocks on the bank lending channel: Evidence from India. International Review of Economics \& Finance, 52, 2017, pp 55-76.

[16] Kumar, M. A., Harsha, G. S., Anand, S., \& Dhruva, N. R, Analyzing soundness in Indian banking: A CAMEL approach. Research Journal of Management Sciences, 1(3), 2012, pp 9-14.

[17] Ankur Bhushan and Dr. Giriraj Singh Ahirwar. A Comparative Study of NPA in HDFC \& OBC Bank. International Journal of Advanced Research in Management, 7(3), 2016, pp. $10-20$.

[18] Popovici, M. C, Measuring Banking Efficiency By Using ROAA And ROAE: Evidence From The European Union. CES Working Papers, 6(1), 2014, pp 146-153.

[19] Robin, I., Salim, R., \& Bloch, H, Financial performance of commercial banks in the postreform era: Further evidence from Bangladesh. Economic Analysis and Policy, 58, 2018, pp 43-54.

[20] Roman, A., \& Şargu, A. C, Analyzing the financial soundness of the commercial banks in Romania: an approach based on the camel's framework. Procedi economics and finance, 6 , 2013, pp 703-712.

[21] Dr. C. Swarnalatha and Mr. R. Gopalakrishnan, A Comparative Study on Occupational Stress of Nationalised And Non Nationalised Bank Employees In Madurai City, Tamil Nadu, India, International Journal of Management (IJM), Volume 3, Issue 1, January- April (2012)

[22] Aditi Kejriwal, A Comparative Analysis of Organizational Role Stress among the Private and Public Sector Bank Officials in Jorhat, Assam, Journal of Management (JOM), 6 (3), 2019, pp. 106-116

[23] SakthiVadivel, M, Financial Efficacy of Selected Public and Private Sector Banks in India. International Journal of Finance \& Banking Studies, 2(2), 2013, pp 26-31 
[24] Shahhoseini, M. A., Khassehkhan, S., \& Shanyani, N, Identifying Key Performance Indicators of an Iranian Islamic Bank Based on BSC and AHP. Journal of American Science, $8(1 \mathrm{~s}) .8(1 \mathrm{~s}), 2012$, pp 64-73

[25] Mohammed Saad Kamel, A Numerical Study of Heat Transfer and Fluid Flow in a Bank of Tubes With Integral Wake Splitter, International Journal of Mechanical Engineering and Technology (IJMET), Volume 5, Issue 12, December (2014), pp. 36-46

[26] Shanmugam, K. R., \& Das, A, The efficiency of Indian commercial banks during the reform period. Applied Financial Economics, 14(9), 2004, pp 681-686.

[27] Srinivasan, \& Saminathan, Y. P, A Camel Model Analysis of Public, Private and Foreign Sector Banks in India. Pacific Business Review International, 8(9), 2016, pp 45-57.

[28] Trivedi, K. R, A camel model analysis of scheduled urban co-operative bank in Surat CityA case study of Surat people ${ }^{e} \mathrm{~s}$ cooperative bank. IOSR Journal of Business and Management, 2013, pp 48-54.

[29] Wanke, P., Azad, M. A. K., \& Barros, C. P, Efficiency factors in OECD banks: A ten-year analysis. Expert Systems with Applications, 64, 2016, pp 208-227.

[30] Waraich.S and Dhawan.A, Performance Evaluation of Cooperative Banks of Punjab: An Application of Camel Model in Terms of Capital Adequacy and Asset Quality, International Journal of Science, Technology \& Management, 2(12),2013, pp 30-39 